\title{
Research Square \\ Dietary patterns and smartphone use in adolescents: A large-sample, cross-sectional study
}

\section{Kyoung Min Kim}

Dankook University College of Medicine

Ilju Lee

Duksung Women's University

\section{Jun Won Kim}

Catholic University of Daegu School of Medicine

Jae-Won Choi ( $\square$ lingker77@naver.com )

Gyeongsang National University Hospital https://orcid.org/0000-0002-4516-1954

\section{Research}

Keywords: adolescents, dietary patterns, large sample, smartphone use

Posted Date: June 8th, 2020

DOI: https://doi.org/10.21203/rs.3.rs-33267/v1

License: (c) (i) This work is licensed under a Creative Commons Attribution 4.0 International License. Read Full License 


\section{Abstract}

Background: This study aimed to examine whether the frequency of consuming specific foods was associated with smartphone usage time and the problems caused by smartphone overuse in adolescents.

Methods: Both routines (food consumption and smartphone use) were investigated in a large sample of Korean adolescents using a nationwide self-report survey. Food intake was assessed using a seven-point scale ("never" to "1, 2, and 3 or more times per day") for nine items: fruits, vegetables, milk, soda, energy drinks, sweetened beverages, fast food, instant noodles, and snacks. Smartphone usage time and problematic usage were determined using self-report items. The study took place in Korea. In total, 62,276 students aged 12-18 years participated.

Results: Most respondents (66.5\%) used smartphones for over two hours per day. Higher rates of consuming fruits, vegetables, and milk were associated with significantly lower smartphone usage; in contrast, higher consumption of soda, energy drinks, sweetened beverages, fast food, instant noodles, and snacks was associated with higher smartphone use.

Conclusions: Our findings provide useful clinical information regarding adolescents' mental health. Future studies should investigate underlying mechanisms and examine the efficacy of adopting dietary interventions for adolescents with excessive smartphone use.

\section{Introduction}

Adolescence is a period of significant emotional, cognitive, and behavioral developmental changes, and these changes are strongly influenced by various social factors at the individual, family, community, and national levels [1]. Notably, the mental health of adolescents is associated with various daily health-related behaviors, such as sleep [2], physical activity [3], diet [4], screen time [5], substance abuse [6], and school violence [7].

Since the unveiling of the iPhone in 2007 [8], the smartphone has rapidly penetrated the daily life of both adolescents and adults, and it has now become an important daily routine in the lives of adolescents. In $2015,92 \%$ of teens were reported to go online daily, and only $8 \%$ of teens were online less than once per day [9]. In 2018, $95 \%$ of U.S. adolescents were reported to have their own smartphones or access to one, and $45 \%$ of teens were online on a near-constant basis [10]. Importantly, previous research has suggested that excessive smartphone use is associated with unfavorable outcomes for adolescents' mental health, such as depression and anxiety [11] [12].

Notably, the problematic or maladaptive use of smartphones by adolescents has rapidly become a widespread social concern [13]. Researchers have not yet reached a consensus regarding smartphone addiction in adolescence, which has led to the use of various methodologies and concepts in the study of this phenomenon, including addiction, dependence, problematic use, and abuse [13]. Despite the lack of conceptual delimitation, several studies have reported substantial concerns for smartphone addiction with a wide prevalence range of $0.4-64 \%$ [13]. Among the various biopsychosocial factors related to the addictive disorders, impulsivity and sensation seeking are considered as the most important individual characteristics predicting smartphone abuse [14][15][16]. 
Dietary habits are another important daily routine associated with adolescents' mental health. Although eating was originally considered a hedonic behavior stimulating the brain reward circuit, there is controversy around framing addictive-like eating problems as "eating addiction" versus "food addiction" [17][18]. Whereas the framework of "eating addiction" suggests a behavioral addiction triggering an addictive-like response in susceptible individuals, the "food addiction" model focuses on the questions of whether certain foods provoke more addictive-like eating behavior than other foods. Despite this controversy, multiple studies have reported that some kinds of food might affect neurobiological changes, provoking addictive-like eating more than other foods [19]. For instance, frequent consumption of highly processed food with high fat, salt, and sugar content, such as soda, pizza, and snacks, increases the individual's impulsivity and craving for food [20][21][22][23]. On the other hand, the Mediterranean diet, which includes fiber-rich fruit and vegetables, has been reported to decrease impulsivity [24].

Interestingly, it has been suggested that the overuse of smartphones and the high consumption of some specific dietary contents share a neurobiological mechanism that might be associated with addictive-like behavior. However, to our knowledge, there is a lack of studies on the direct associations between smartphone overuse and specific dietary patterns. Thus, our study aimed to examine whether the frequency of consuming specific foods is associated with smartphone usage time and the problems caused by smartphone overuse.

\section{Methods}

\section{Participants}

Our study analyzed data from the 2017 Korean Youth Risk Behavior Web-based Survey (KYRBS), which is a nationwide, self-report, cross-sectional study conducted by the Korean Centers for Disease Control and Prevention [25]. The target population for the 2017 survey was 64,991 nationally representative students from 400 middle and 400 high schools, aged 12 to 18 years, in Korea. A total of 62,276 (95.8\%) adolescents participated in the survey.

\section{Measures}

To assess food intake frequency, a self-rated questionnaire was used that included nine items: fruits, vegetables, milk, soda, caffeinated energy drinks, sweetened beverages, fast food (i.e., pizza, hamburgers, and fried chicken), instant noodles, and snacks. Consumption of each item was rated on a seven-point rating scale (never, 1 to 2, 3 to 4, and 5 to 6 times per week, and 1, 2, and more than 3 times per day).

Smartphone usage time was assessed with the following item: "How many hours and minutes per day have you used a smartphone in the last 30 days?" Smartphone usage time was categorized into weekdays and weekends, and the average daily hours of use on weekdays and weekends were used in the subsequent analysis.

The problems related to conflicts with the family and disturbances in school performance caused by smartphone use were assessed using one item for each problem as rated on a four-point Likert scale, with responses from 1 = strongly disagree to 4 = strongly agree. The items were "I have experienced severe conflicts with my family because of smartphone use" and "Due to the use of smartphones, there are 
difficulties in carrying out my studies." In our study, the high-risk group for problems caused by smartphone use was defined based on responses of agree or strongly agree to each item.

\section{Procedure}

The students were provided with detailed instructions about the study by trained teachers before completing the survey. Students who agreed to participate responded to an anonymous, self-administered, web-based questionnaire presented on a computer screen. Before participation in the survey, the students were provided with an online informed consent form which was signed before completing the questionnaire. The steering committee representing the Office of Education from 17 provinces of Korea oversaw the survey.

\section{Statistical analysis}

Smartphone usage time and problems caused by smartphone use were compared among the groups according to the consumption frequency of each food. For the comparison of smartphone usage time, the groups of " 1,2 , and more than 3 times per day" were merged into one group of "more than 1 time," given the small proportion of participants in those frequency groups. Differences in smartphone usage time among the food intake frequency groups were analyzed by three models. Model 1 was analyzed using analysis of variance, with the consumption frequency of each kind of food as the independent variables and smartphone usage time as the dependent variable, while Model 2 was analyzed using analysis of covariance, including sex, age, and socioeconomic status as the covariates. Model 3 included parental educational levels as covariates in addition to those in Model 2. Post-hoc analyses were conducted using Tukey's honest significant difference test in Model 2 due to many missing values for parental educational level. The odds ratio for the high-risk group of conflict with family and disturbances in school performance caused by excessive smartphone use was analyzed using a logistic regression model with the categories of foods as the independent variables. The statistical analyses were conducted using the software package SPSS 25.0 for Windows (IBM Corp., Armonk, NY, USA).

\section{Results}

\section{Demographic characteristics}

The demographic characteristics of the participants are shown in Table 1. Among the 62,276 participating youths, 31,624 (50.8\%) were male. A small proportion of adolescents (12.3\%) had not used a smartphone in the past 30 days. Two-thirds (66.5\%) used a smartphone for over 2 hours per day and $5.3 \%$ used a smartphone for more than 10 hours per day.

\section{Association between food intake frequency and smartphone usage time}

Food intake frequency is shown in Table 2. Responses of " 1 to 2 times per week" had the most prevalent frequency for fruits, milk, soda, sweetened beverages, fast food, instant noodles, and snacks; “3 to 4 times per week" was most prevalent for vegetables, and "never" was most prevalent for caffeinated energy drinks. Responses of " 2 times per day" and "more than 3 times per day" for soda, caffeinated energy drinks, sweetened beverages, fast food, instant noodles, and snacks were very low (under $2 \%$ ). 
Table 3, Figure 1, and Figure 2 show the association between the food intake frequency and smartphone usage time. Higher rates of consuming fruits $(F=151.8 ; p<0.001)$, vegetables $(F=119.9 ; p<0.001)$, and milk $(F=33.0 ; p<0.001)$ were associated with significantly lower smartphone usage. In contrast, higher consumption of soda $(F=292.5 ; p<0.001)$, energy drinks $(F=24.0 ; p<0.001)$, sweetened beverages $(F=$ 224.8; $p<0.001)$, fast food $(F=192.1 ; p<0.001)$, instant noodles $(F=196.2 ; p<0.001)$, and snacks $(F=$ 131.6; $p<0.001$ ) were associated with higher smartphone use.

\section{Association between food intake frequency and problems caused by smartphone use}

The odds ratios for the high-risk groups of conflict with family and disturbances in school performance caused by excessive smartphone use increased with more frequent consumption of soda, caffeinated energy drinks, sweetened beverages, fast food, instant noodles, and snacks (Table 4). The odds ratios also increased with less frequent intake of vegetables. However, a higher intake frequency of fruit was more strongly associated with an increased odds ratio in conflict with family, whereas milk had no significant associations with the ratio for conflict with family.

The scores of the items for problems caused by smartphone use were significantly different among the groups of food intake frequencies (Table S1). Higher levels of consuming fruits, vegetables, and milk, and lower levels of consuming soda, caffeinated energy drinks, sweetened beverages, fast food, instant noodles, and snacks were significantly associated with fewer problems caused by smartphone use. However, the average scores of problems caused by smartphone use items were under two ("disagree") in all the food intake frequency groups.

\section{Discussion}

The present study investigated the association between excessive smartphone use and dietary habits in Korean adolescents using a cross-sectional design with a large sample. Most participating adolescents $(87.7 \%)$ reported that they had used a smartphone in the last 30 days, and $66.5 \%$ reported using a smartphone for over two hours per day. These findings indicate the pervasive use of smartphones by adolescents and are comparable with U.S. studies that found that $92 \%$ of teens reported going online daily and $45 \%$ were online "almost constantly" [10][9].

The major findings of the present study are the significant associations between specific dietary patterns and smartphone usage time. Adolescents who consume more soda, sweetened beverages, drinks with a high level of caffeine, fast food, instant noodles, and snacks, which could be labeled as addictive food, spent more time using a smartphone. In contrast, frequent intake of fruits and vegetables was linearly associated with lower levels of smartphone usage. Intake of milk was also associated with lower smartphone usage, although the association was less strong compared to fruits and vegetables. To our knowledge, our study presents novel findings, in that there have been no previous studies of the association between smartphone use and dietary habits in adolescents. In particular, the linearity of the associations between the consumption frequency of specific foods and smartphone usage time is interesting, although the effect size of the associations is small. Consistent with our findings, previous studies have reported associations between psychiatric symptoms and dietary patterns in disorders characterized by impulsivity and vulnerability to addiction, such as Attention- 
Deficit/Hyperactivity Disorder (ADHD) [26][27][28], binge-eating disorder [29], and gambling [30]. For instance, Kim et al reported linear associations between scores on ADHD symptoms (hyperactivity and inattention) and the consumption frequency of specific foods in the general population of school-aged children [27].

The fifth edition of the Diagnostic and Statistical Manual of Mental Disorders has included internet gaming disorder in the section "Conditions for Further Study" [31], and gaming disorder was listed as a formal diagnosis in the International Classification of Diseases 11th Revision, released in 2018 [32]. Although excessive smartphone use has not yet been agreed upon as a formal mental disorder, the addictive potential of excessive smartphone use should be studied carefully, considering that internet gaming is one of the major uses of smartphones and that smartphones are widely accessible at any time. Impulsivity and altered reward circuit activation in the brain are the shared neurobiological features in the disorders vulnerable to addiction, such as ADHD and substance abuse [33][34]. These are also the major predictive dimensions of excessive smartphone use [35][13]. Dietary patterns are also known to affect impulsivity and reward circuit activation [18].

Although the concept of food addiction is a controversial topic and there is no consensus on whether humans show addictive-like eating [37], previous animal studies indicate that high consumption levels of high-fat and high-sugar foods induce neurobiological changes, such as dysfunction of the reward system and

downregulation of dopamine receptors observed in other addictive disorders [37][38][18]. Human studies have also suggested evidence for the addictive potential of hyperpalatable food via neural activation in addictivelike eating behavior and substance dependence, such as altered activation in the reward circuit [39][40][37] [19].

In contrast to addictive high-fat, high-sugar, and highly processed foods, the Mediterranean diet, which is rich in fruits and vegetables, has been reported to be negatively associated with impulsivity and sensation-seeking [41]. Food addictions are also associated with a lower intake of the Mediterranean diet [36]. These results are consistent with the findings of the present study. Despite multiple studies suggesting a protective association of fruit and vegetable intake with impulsivity and vulnerability to addiction, the underlying mechanism has not yet been identified clearly. However, studies have hypothesized some mechanisms, including phytochemicals, short chain fatty acids, and the antioxidant properties in fruit and vegetables, and have reported positive evidence for their neuroprotective effect [42].

Even though dietary patterns had a significant linear association with smartphone usage time in our study, dietary patterns do not necessarily cause smartphone "addiction" directly. For "addiction," in addition to excessive use, other elements (such as social impairment, tolerance, and failure to control behavior) also must be present [13]. Our study found relatively inconsistent associations for the odds ratios for the problems caused by smartphone use among the food intake frequency groups, compared to a linear association between dietary habit and smartphone usage time. These findings might suggest that the effect of dietary patterns on smartphone use is not so strong as to elicit the label of smartphone "addiction"; however, it may be that diet can contribute to the vulnerability to addiction by changing the underlying neural mechanism of the reward circuit activation. Previous studies also have reported consistent findings regarding the addictive potential of foods. Twenty-one studies and twelve studies included in a systematic review about "food addiction" reported evidence of brain reward system dysfunction and impaired control according to food 
intake, respectively, which indicates the existence of a change in neurobiological function caused by dietary habits [19]. However, only two studies reported evidence for social impairment caused by "food addiction" [19]. These studies suggest that addiction involves more social factors in addition to neurobiological change, which is in line with our findings.

\section{Limitations}

There are some limitations to this study that should be noted. First, it used a cross-sectional design, which limits the ability to determine causal relationships. Children and adolescents who are vulnerable to addiction and whose sensation-seeking and impulsive temperament are high might share the common features of smartphone overuse and frequent intake of addictive food. However, previous studies reported that dietary intervention can change the core symptoms in children with ADHD. In addition, Lumley et al. reported that greater impulsivity is associated with consuming a Western-style diet, with bidirectional causation [43]. Considering these previous studies, smartphone usage might be influenced by long-term dietary patterns. However, longitudinal or experimental studies are needed to confirm the exact causal relationship.

Second, our study was based only on an anonymous, self-reported questionnaire completed by participants, and it is possible that adolescents inaccurately reported their dietary patterns and smartphone use. In addition, although we included items to evaluate the problems caused by smartphone use, validated tools to assess the severity of smartphone abuse in terms of addiction criteria were not adopted in our study. Thus, future studies that include multi-informant reports and objective measures assessing children's behavior are needed to confirm the findings of our study. Importantly, a previous study examining the correspondence between adolescent and parent reports for psychiatric symptoms found that the adolescents' reports for substance abuse were more accurately correlated with the real diagnosis than the parents' reports [44]. This suggests that reports from adolescents can be viewed as reliable.

Finally, our study was performed using a typically developing population, which limits the generalizability of the findings to the populations with addictive psychopathology, such as ADHD, substance abuse, and eating disorders. To confirm the present findings, future studies in groups with psychiatric disorders are warranted.

\section{Conclusion}

Diet is a major but modifiable daily routine of adolescents, and dietary interventions could be improved by knowing the psychological characteristics related to consuming each kind of food. Despite several limitations, our study is the first to reveal a relationship between dietary patterns and smartphone overuse with a large sample of adolescents. The present findings of a linear relationship between dietary patterns and smartphone overuse are interesting. The smartphone is an important environmental factor today that induces great concerns for adolescents' mental health at the family and societal level. Although dietary habits are not a critical contributor to smartphone addiction, future studies investigating interventions with diet and smartphone use could help improve adolescents' mental health.

\section{Declarations}


Ethics approval and consent to participate

The Institutional Review Board of the Dankook University Hospital (DKUH 2019-07-022) approved the current study.

\section{Consent for publication}

Not applicable.

\section{Availability of data and materials}

The use of the data from the 2017 Korean Youth Risk Behavior Web-based Survey (KYRBS repository, https://yhs.cdc.go.kr) was permitted by the Korea Centers for Disease Control and Prevention.

\section{Competing interests}

The authors declare no conflict of interest.

\section{Funding}

This research did not receive any specific grant from funding agencies in the public, commercial, or not-forprofit sectors.

\section{Authors' Contributions}

Conceptualization: J.W.C.; data curation: K.M.K., I.L.; formal analysis: J.W.K., K.M.K.; project administration: K.M.K.; supervision: J.W.C.; writing-original draft: K.M.K.; writing-review and editing: J.W.C., K.M.K., J.W.K., I.L. All authors have read and agreed to the published version of the manuscript.

\section{Acknowledgements}

The authors wish to thank the Korea Centers for Disease Control and Prevention, which provided the raw data for this study. This research did not receive any specific grant from funding agencies in the public, commercial, or not-for-profit sectors.

\section{References}

1. Viner RM, Ozer EM, Denny S, Marmot M, Resnick M, Fatusi A, Currie C. Adolescence and the social determinants of health. Lancet. 2012;379:1641-52. https://doi.org/10.1016/S0140-6736(12)60149-4.

2. Shochat T, Cohen-Zion M, Tzischinsky Sleep Medicine Reviews. 2014;18:750. Functional consequences of inadequate sleep in adolescents: A systematic review.-87. https://doi.org/10.1016/j.smrv.2013.03.005.

3. Biddle SJH, Asare M. Physical activity and mental health in children and adolescents: A review of reviews. Br J Sports Med. 2011;45:886-95. https://doi.org/10.1136/bjsports-2011-090185.

4. Murakami K, Sasaki S. Dietary intake and depressive symptoms: A systematic review of observational studies. Mol Nutr Food Res. 2010;54:471-88. https://doi.org/10.1002/mnfr.200900157. 
5. Costigan SA, Barnet L, Plotnikoff FF, Luban DR. The health indicators associated with screen-based sedentary behavior among adolescent girls: A systematic review. J Adolesc Health. 2013;52:382-92. https://doi.org/10.1016/j.jadohealth.2012.07.018.

6. Gray KM, Squeglia LM. Research review: What have we learned about adolescent substance use? J Child Psychol Psychiatry. 2018;59:618-27. https://doi.org/10.1111/jcpp.12783.

7. Bottino SMB, Bottino CMC, Regina CG, Correia AVL, Ribeiro WS. Cyberbullying e saúde mental dos adolescentes: revisão sistemática [Cyberbullying and adolescent mental health: systematic review]. Cademos de Saúde Pública. 2015;31:463-75. https://doi.org/10.1590/0102-311X00036114.

8. Andrew O. The history and evolution of the smartphone: 1992-2018. https://www.textrequest.com/blog/history-evolution-smartphone.

9. Lenhart A. Teens, social media \& technology overview. Washington, DC: Pew Research Center. 2015. https://www.pewinternet.org/2015/04/09/teens-social-media-technology-2015/.

10. Anderson M, Jiang J. Teens, social media \& technology. 2018. Washington, DC: Pew Research Center. 2018. http://publicservicesalliance.org/wp-content/uploads/2018/06/Teens-Social-Media-Technology2018-PEW.pdf.

11. Elhai JD, Dvorak RD, Levine JC, Hall BJ. Problematic smartphone use: A conceptual overview and systematic review of relations with anxiety and depression psychopathology. J Affect Disord. 2017;207:251-9. https://doi.org/10.1016/j.jad.2016.08.030.

12. Kim Y-J, Jang HM, Lee Y, Lee D, Kim D-J. Effects of internet and smartphone addictions on depression and anxiety based on propensity score matching analysis. International Journal of Environmental Research Public Health. 2018;15:859. https://doi.org/10.3390/ijerph15050859.

13. $10.3389 /$ fpsyt.2016.00175

De-Sola Gutiérrez J, Rodríguez de Fonseca F, Rubio G. (2016). Cell-phone addiction: A review. Frontiers in Psychiatry, 2016;7:175. https://doi.org/10.3389/fpsyt.2016.00175.

14. Kim Y, Jeong J-E, Cho H, Jung D-J, Kwak M, Rho MJ, et al. Personality factors predicting smartphone addiction predisposition: Behavioral inhibition and activation systems, impulsivity, and self-control. PloS One. 2016;11(8):e0159788. https://doi.org/10.1371/journal.pone.0159788.

15. Peterka-Bonetta J, Sindermann C, Elhai JD, Montag C. Personality associations with smartphone and Internet use disorder: A comparison study including links to impulsivity and social anxiety. Frontiers in Public Health. 2019;7:127. https://doi.org/10.3389/fpubh.2019.00127.

16. Roberts JA, Pullig C, Manolis C. I need my smartphone: a hierarchical model of personality and cellphone addiction. Personality Individ Differ. 2015;79:13-9. https://doi.org/10.1016/j.paid.2015.01.049.

17. Hebebrand J, Albayrak O, Adan R, Antel J, Diegues C, de Jong, J. et al. ... Eating addiction,"rather than "food addiction," better captures addictive-like eating behavior. Neuroscience\& Biobehaval Reviews, 2014;47:295-306. https://doi.org/10.1016/j.neubiorev.2014.08.016.

18. Schulte EM, Potenza MN, Gearhardt AN. A commentary on the "eating addiction" versus "food addiction" perspectives on addictive-like food consumption. Appetite. 2017;115:9-15. https://doi.org/10.1016/j.appet.2016.10.033. 
19. Gordon EL, Ariel-Donges AH, Bauman V, Merlo LJ. What is the evidence for "food addiction?" A systematic review. Nutrients. 2018;10:477. https://doi.org/10.3390/nu10040477.

20. Gilhooly C, Das SK, Golden JK, McCrory MA, Dallal JE, Saltzman FM, et al. Food cravings and energy regulation: the characteristics of craved foods and their relationship with eating behaviors and weight change during 6 months of dietary energy restriction. International Journal of Obesity. 2007;31:1849-58. https://doi.org/10.1038/sj.ijo.0803672.

21. Schulte EM, Avena NM, Gearhardt AN. Which foods may be addictive? The roles of processing, fat content, and glycemic load. PloS One. 2015;10(2):e0117959.

https://doi.org/10.1371/journal.pone.0117959.

22. Smith DG, Robbins TW. The neurobiological underpinnings of obesity and binge eating: A rationale for adopting the food addiction model. Biol Psychiat. 2013;73:804-15.

https://doi.org/10.1016/j.biopsych.2012.08.026.

23. Steele CC, Pirkle JR, Kirkpatrick K. Diet-induced impulsivity: Effects of a high-fat and a high-sugar diet on impulsive choice in rats. PloS One. 2017;12(6):e0180510. https://doi.org/10.1371/journal.pone.0180510.

24. Impulsividad en el trastorno por déficit de atención e hiperactividad en niños después de una intervención de 8 semanas con dieta mediterránea y/o ácidos grasos omega-3:

https://doi.org/10.1016/j.nrl.2019.09.007

Advance online publication

San Mauro Martin I, Sanz Rojo S, González Cosano L, Conty de la Campa R, Garicano Vilar E, Blumenfeld Olivares JA. Impulsividad en el trastorno por déficit de atención e hiperactividad en niños después de una intervención de 8 semanas con dieta mediterránea y/o ácidos grasos omega-3: Ensayo clínico aleatorizado [Impulsiveness in children with attention-deficit/hyperactivity disorder after an 8-week intervention with the Mediterranean diet and/or omega-3 fatty acids: A randomised clinical trial]. Neurología. 2020. Advance online publication. https://doi.org/10.1016/j.nrl.2019.09.007.

25. $10.1093 /$ ije/dyw070

Kim Y, Choik S, Chun C, Park S, Khang Y-H, Oh K Data resource profile: The Korea Youth Risk Behavior Web-Based Survey (KYRBS). International Journal of Epidemiology, 2016;45:1076-1076e. https://doi.org/10.1093/ije/dyw070.

26. Howard AL, Robinson M, Smith GJ, Ambrosini LA, Piek JP, Oddy WH. ADHD is associated with a “Western" dietary pattern in adolescents. Journal of Attention Disorders. 2011;15:403-11. https://doi.org/10.1177/1087054710365990.

27. Kim KM, Lim MH, Kwon HJ, Yoo S-J, Kim E-J, Kim JW, et al. Associations between attentiondeficit/hyperactivity disorder symptoms and dietary habits in elementary school children. Appetite. 2018;127:274-9. https://doi.org/10.1016/j.appet.2018.05.004.

28. Ríos-Hernández A, Alda JA, Farran-Codina A, Ferreira-García E, Izquierdo-Pulido M. The Mediterranean diet and ADHD in children and adolescents. Pediatrics. 2017;139:2016-27. https://doi.org/10.1542/peds.2016-2027.

29. Bertoli S, Spadafranca A, Bes-Rastrollo M, Martinez-Gonzalez MA, Ponissi V, Beggio V, et al. Adherence to the Mediterranean diet is inversely related to binge eating disorder in patients seeking a weight loss program. Clin Nutr. 2015;34:107-14. https://doi.org/10.1016/j.clnu.2014.02.001. 
30. Chamberlain SR, Redden AS, Grant JE. Calorie intake and gambling: Is fat and sugar consumption 'impulsive'? J Gambl Stud. 2017;33:783-93. https://doi.org/10.1007/s10899-016-9647-1.

31. Grant JE, Atmaca M, Fineberg NA, Fontenelle LF, Matsunaga H, Reddy YC, et al. Impulse control disorders and "behavioural addictions" in the ICD-11. World Psychiatry. 2014;13:125-7. https://doi.org/10.1002/wps.20115.

32. Brand M, Rumpf H-J, Demetrovics Z, King DL, Potenza MN, Wegmann E. Gaming disorder is a disorder due to addictive behaviors: Evidence from behavioral and neuroscientific studies addressing cue reactivity and craving, executive functions, and decision-making. Current Addiction Reports. 2019;6:296302. https://doi.org/10.1007/s40429-019-00258-y.

33. Stark R, Bauer E, Merz CJ, Zimmermann M, Reuter M, Plichta MM, et al. ADHD related behaviors are associated with brain activation in the reward system. Neuropsychologia. 2011;49:426-34. https://doi.org/10.1016/j.neuropsychologia.2010.12.012.

34. Volkow ND, Wang GJ, Fowler JS, Tomasi D, Telang F, Baler R. Addiction: decreased reward sensitivity and increased expectation sensitivity conspire to overwhelm the brain's control circuit. Bioessays. 2010;32:748-55. https://doi.org/10.1002/bies.201000042.

35. 10.3389/fpsyt.2018.00437

Chun J-W, Choi J, Cho H, Choi M-R, Ahn K-J, Choi JS, Kim D-J. (2018). Role of frontostriatal connectivity in adolescents with excessive smartphone use. Frontiers in Psychiatry, 2018;9:437. https://doi.org/10.3389/fpsyt.2018.00437.

36. Burrows T, Hides L, Brown R, Dayas CV, Kay-Lambkin F. Differences in dietary preferences, personality and mental health in Australian adults with and without food addiction. Nutrients. 2017;9(3):285. https://doi.org/10.3390/nu9030285.

37. Gearhardt AN, Yokum S, Orr PT. Neural correlates of food addiction. Arch Gen Psychiatry. 2011;68:80816. https://doi.org/10.1001/archgenpsychiatry.2011.32.

38. Kalon E, Hong JY, Tobin C, Schulte T. Psychological and neurobiological correlates of food addiction. Int Rev Neurobiol. 2016;129:85-110. https://doi.org/10.1016/bs.irn.2016.06.003.

39. Davis C, Curtis C, Levitan RD, Carter JC, Kaplan AS, Kennedy JL. Evidence that 'food addiction' is a valid phenotype of obesity. Appetite. 2011;57:711-7. https://doi.org/10.1016/j.appet.2011.08.017.

40. Gearhardt AN, Davis C, Kuschner R, Brownell KD. The addiction potential of hyperpalatable foods. Curr Drug Abuse Rev. 2011;4:140-5. https://doi.org/10.2174/1874473711104030140.

41. Stevenson RJ. Psychological correlates of habitual diet in healthy adults. Psychol Bull. 2017;143:53-90. https://doi.org/10.1037/bul0000065.

42. Sandhu KV, Sherwin E, Schellekens H, Stanton C, Dinan TG, Cryan JF. Feeding the microbiota-gut-brain axis: diet, microbiome, and neuropsychiatry. Translational Research. 2017;179:223-44. https://doi.org/10.1016/j.trsl.2016.10.002.

43. Lumley J, Stevenson RJ, Oaten MJ, Mahmut M, Yeomans MR. Individual differences in impulsivity and their relationship to a Western-style diet. Personality Individ Differ. 2016;97:178-85. https://doi.org/10.1016/j.paid.2016.03.055. 
44. Cantwell DP, Lewinsohn PM, Rohde P, Seeley JR. Correspondence between adolescent report and parent report of psychiatric diagnostic data. J Am Acad Child Adolesc Psychiatry. 1997;36:610-9. https://doi.org/10.1097/00004583-199705000-00011.

\section{Tables}

Table 1. Demographics characteristics

\begin{tabular}{lc}
\hline \multicolumn{1}{c}{ Variables } & $\mathbf{n}(\%)$ \\
\hline Sex & \\
\hline Male & $31,624(50.8)$ \\
\hline Female & $30,652(49.2)$ \\
\hline Age (years) & \\
\hline 12 & $4,987(8.0)$ \\
\hline 13 & $10,280(16.5)$ \\
\hline 14 & $10,286(16.5)$ \\
\hline 15 & $10,335(16.6)$ \\
\hline 16 & $10,707(17.2)$ \\
\hline 17 & $10,874(17.5)$ \\
\hline 18 & $4,392(7.1)$ \\
\hline unknown & $415(0.7)$ \\
\hline
\end{tabular}

Smartphone usage time ( $\mathrm{H}$; hours per day)

$\begin{array}{lc}\text { never } & 7,675(12.3) \\ \mathrm{H} \square 1 & 3,551(5.7) \\ 1 \leq \mathrm{H} \square 2 & 9,627(15.5) \\ 2 \leq \mathrm{H} \square 4 & 21,305(34.2) \\ 4 \leq \mathrm{H} \square 6 & 10,500(16.9) \\ 6 \leq \mathrm{H} \square 8 & 4,377(7.0) \\ 8 \leq \mathrm{H} \square 10 & 1,957(3.1) \\ \mathrm{H} \geq 10 & 3,284(5.3)\end{array}$

Socioeconomic status

\begin{tabular}{lc}
\hline High & $6,713(10.8)$ \\
\hline High-middle & $18,089(29.0)$ \\
\hline Middle & $28,582(45.9)$ \\
\hline Low-middle & $7,299(11.7)$ \\
\hline Low & $1,593(2.6)$ \\
\hline Paternal educational level & \\
\hline$\leq 12$ years & $17,094(27.4)$ \\
\hline$>12$ years & $31,535(50.6)$ \\
\hline unknown & $13,647(21.9)$ \\
\hline Maternal educational level & \\
\hline$\quad 12$ years & $20,436(32.8)$ \\
\hline$>12$ years & $29,005(46.6)$ \\
\hline unknown & $12,835(20.6)$ \\
\hline
\end{tabular}

Table 2. Food intake frequency; n(\%) 


\begin{tabular}{|c|c|c|c|c|c|c|c|}
\hline Food category & never & $\begin{array}{c}1-2 \\
\text { times/week }\end{array}$ & $\begin{array}{c}3-4 \\
\text { times/week }\end{array}$ & $\begin{array}{c}5-6 \\
\text { times/week }\end{array}$ & $\begin{array}{c}1 \\
\text { time/day }\end{array}$ & $\begin{array}{c}2 \\
\text { times/day }\end{array}$ & $\begin{array}{c}\text { more than } 3 \\
\text { times/day }\end{array}$ \\
\hline Fruit & $\begin{array}{l}6,242 \\
(10.0)\end{array}$ & $\begin{array}{l}18,361 \\
(29.5)\end{array}$ & $\begin{array}{l}16,903 \\
(27.1)\end{array}$ & $\begin{array}{l}7,014 \\
(11.3)\end{array}$ & $\begin{array}{l}7.406 \\
(11.9)\end{array}$ & $\begin{array}{l}3,604 \\
(5.8)\end{array}$ & $2,744(4.4)$ \\
\hline Vegetable & $\begin{array}{l}2,597 \\
(4.2)\end{array}$ & $\begin{array}{l}9,893 \\
(15.9)\end{array}$ & $\begin{array}{l}14,886 \\
(23.9)\end{array}$ & $\begin{array}{l}8,605 \\
(13.8)\end{array}$ & $\begin{array}{l}8,377 \\
(13.5)\end{array}$ & $\begin{array}{l}8,638 \\
(13.9)\end{array}$ & $9,280(14.9)$ \\
\hline Milk & $\begin{array}{l}9,047 \\
(14.5)\end{array}$ & $\begin{array}{l}15,468 \\
(24.8)\end{array}$ & $\begin{array}{l}13,064 \\
(21.0)\end{array}$ & $\begin{array}{l}8,726 \\
(14.0)\end{array}$ & $\begin{array}{l}10,224 \\
(16.4)\end{array}$ & $\begin{array}{l}3,273 \\
(5.3)\end{array}$ & $2,473(4.0)$ \\
\hline Soda & $\begin{array}{l}13,042 \\
(20.9)\end{array}$ & $\begin{array}{c}28,381 \\
(45.6)\end{array}$ & $\begin{array}{l}13,796 \\
(22.2)\end{array}$ & $3,774(6.1)$ & $\begin{array}{l}1,745 \\
(2.8)\end{array}$ & $750(1.2)$ & 788 (1.3) \\
\hline $\begin{array}{l}\text { Caffeinated } \\
\text { energy drink }\end{array}$ & $\begin{array}{l}47,435 \\
(76.2)\end{array}$ & $\begin{array}{l}9,969 \\
(16.0)\end{array}$ & $2,962(4.8)$ & 835 (1.3) & $595(1.0)$ & $244(0.4)$ & $236(0.4)$ \\
\hline $\begin{array}{l}\text { Sweetened } \\
\text { beverage }\end{array}$ & $\begin{array}{l}7,810 \\
(12.5)\end{array}$ & $\begin{array}{c}25,300 \\
(40.6)\end{array}$ & $\begin{array}{l}17,913 \\
(28.8)\end{array}$ & $6,052(9.7)$ & $\begin{array}{l}3,108 \\
(5.0)\end{array}$ & $\begin{array}{l}1162 \\
(1.9)\end{array}$ & $931(1.5)$ \\
\hline Fast food & $\begin{array}{l}12,646 \\
(20.3)\end{array}$ & $\begin{array}{l}37,225 \\
(59.8)\end{array}$ & $\begin{array}{l}9,991 \\
(16.0)\end{array}$ & $1,599(2.6)$ & $485(0.8)$ & $139(0.2)$ & $191(0.3)$ \\
\hline Instant noodle & $\begin{array}{l}13,836 \\
(22.2)\end{array}$ & $\begin{array}{l}32,139 \\
(51.6)\end{array}$ & $\begin{array}{l}12,542 \\
(20.1)\end{array}$ & $2,503(4.0)$ & $896(1.4)$ & $163(0.3)$ & $197(0.3)$ \\
\hline Snack & $\begin{array}{l}10,218 \\
(16.4)\end{array}$ & $\begin{array}{c}27,415 \\
(44.0)\end{array}$ & $\begin{array}{l}17,219 \\
(27.6)\end{array}$ & $4,339(7.0)$ & $\begin{array}{l}2,120 \\
(3.4)\end{array}$ & $564(0.9)$ & $401(0.6)$ \\
\hline
\end{tabular}

Table 3. Smartphone usage time among the groups of food intake frequency (hours per day). 


\begin{tabular}{|c|c|c|c|c|c|c|c|c|c|}
\hline \multirow[t]{2}{*}{ Food } & \multirow[t]{2}{*}{ never } & \multirow{2}{*}{$\begin{array}{c}1-2 \\
\text { times/week }\end{array}$} & \multirow{2}{*}{$\begin{array}{c}\text { 3-4 } \\
\text { times/week }\end{array}$} & \multirow{2}{*}{$\begin{array}{c}5-6 \\
\text { times/week }\end{array}$} & \multirow{2}{*}{$\begin{array}{l}1 \text { or more } \\
\text { times/day }\end{array}$} & \multicolumn{3}{|c|}{ Statistics (F) } & \multirow[t]{2}{*}{ post-hoc } \\
\hline & & & & & & $\begin{array}{c}\text { Model } \\
1\end{array}$ & $\begin{array}{c}\text { Model } \\
2\end{array}$ & $\begin{array}{c}\text { Model } \\
3\end{array}$ & \\
\hline Fruit & $\begin{array}{c}4.22 \\
(4.02)\end{array}$ & $3.81(3.51)$ & $3.48(3.22)$ & $3.36(3.18)$ & $\begin{array}{c}3.13 \\
(3.14)\end{array}$ & $151.8^{* *}$ & $98.1 * *$ & $54.6^{* *}$ & $\mathrm{a}>\mathrm{b}>\mathrm{c}=\mathrm{d}>\mathrm{e}$ \\
\hline Vegetable & $\begin{array}{c}4.38 \\
(4.20)\end{array}$ & 3.98 (3.66) & 3.66 (3.35) & $3.41(3.21)$ & $\begin{array}{c}3.31 \\
(3.24)\end{array}$ & $119.9 * *$ & $29.7 * *$ & $20.4^{* *}$ & $\mathrm{a}>\mathrm{b}>\mathrm{c}>\mathrm{d}=\mathrm{e}$ \\
\hline Milk & $\begin{array}{c}3.81 \\
(3.63)\end{array}$ & $3.62(3.34)$ & $3.61(3.38)$ & $3.54(3.34)$ & $\begin{array}{c}3.33 \\
(3.32)\end{array}$ & $33.0 * *$ & $5.1 * *$ & $3.2^{*}$ & $\mathrm{a}>\mathrm{b}=\mathrm{c}=\mathrm{d}>\mathrm{e}$ \\
\hline Soda & $\begin{array}{c}3.03 \\
(2.99)\end{array}$ & 3.39 (3.12) & $3.92(3.59)$ & $4.22(3.9)$ & $\begin{array}{c}4.83 \\
(4.75)\end{array}$ & $292.5^{* *}$ & $112.0^{* *}$ & $77.4^{* *}$ & $\mathrm{a}<\mathrm{b}<\mathrm{c}<\mathrm{d}<\mathrm{e}$ \\
\hline $\begin{array}{l}\text { caffeinated } \\
\text { energe } \\
\text { drink }\end{array}$ & $\begin{array}{c}3.49 \\
(3.27)\end{array}$ & $3.73(3.61)$ & $3.83(3.71)$ & $3.99(4.21)$ & $\begin{array}{c}4.01 \\
(4.64)\end{array}$ & $24.0^{* *}$ & $3.7^{*}$ & $2.6^{*}$ & $\mathrm{a}<\mathrm{c}, \mathrm{d}, \mathrm{e}$ \\
\hline $\begin{array}{c}\text { sweetened } \\
\text { beverage }\end{array}$ & $\begin{array}{c}3.00 \\
(3.14)\end{array}$ & $3.30(3.12)$ & 3.73 (3.37) & $4.07(3.70)$ & $\begin{array}{c}4.44 \\
(4.29)\end{array}$ & $224.8 * *$ & $50.3^{* *}$ & $37.8^{* *}$ & $\mathrm{a}<\mathrm{b}<\mathrm{c}<\mathrm{d}<\mathrm{e}$ \\
\hline Fast food & $\begin{array}{c}3.09 \\
(3.08)\end{array}$ & $3.50(3.26)$ & $4.16(3.78)$ & $4.32(4.19)$ & $\begin{array}{c}4.77 \\
(5.12)\end{array}$ & $192.1 * *$ & $23.0 * *$ & $17.6^{* *}$ & $\mathrm{a}<\mathrm{b}<\mathrm{c}=\mathrm{d}<\mathrm{e}$ \\
\hline $\begin{array}{l}\text { Instant } \\
\text { noodle }\end{array}$ & $\begin{array}{c}3.19 \\
(3.17)\end{array}$ & $3.43(3.19)$ & $3.99(3.64)$ & $4.48(4.18)$ & $\begin{array}{c}4.83 \\
(4.96)\end{array}$ & $196.2 * *$ & $55.5^{* *}$ & $41.2^{* *}$ & $\mathrm{a}<\mathrm{b}<\mathrm{c}<\mathrm{d}<\mathrm{e}$ \\
\hline Snack & $\begin{array}{c}3.24 \\
(3.26)\end{array}$ & $3.42(3.26)$ & $3.66(3.36)$ & $4.11(3.68)$ & $\begin{array}{c}4.53 \\
(4.34)\end{array}$ & $131.6^{* *}$ & $11.8^{* *}$ & $10.8^{* *}$ & $\mathrm{a}<\mathrm{b}<\mathrm{c}<\mathrm{d}<\mathrm{e}$ \\
\hline
\end{tabular}

Model 1 is a crude model with the consuming frequency of each kind of food as independent variable and smartphone use time as a dependent variable.

Model 2 is an adjusted model including sex, age, and socioeconomic status as covariates in addition to model 1. Model 3 included parental educational levels as covariates in addition to model 2

post-hoc : a (never), b (1-2 times/week), c (3-4 times/week), d (5-6 times/week), e (1 or more than 1 time/day) $* \mathrm{p}<0.05 ; * * \mathrm{p}<0.001$

Table 4. Odds ratios for the high-risk group of problems caused by smartphone use according to the food intake frequency. 


\begin{tabular}{|c|c|c|c|c|c|c|}
\hline & \multicolumn{3}{|c|}{ Conflict with family } & \multicolumn{3}{|c|}{ Disturbances in school performance } \\
\hline & Soda & $\begin{array}{l}\text { caffeinated } \\
\text { energe drink }\end{array}$ & $\begin{array}{l}\text { sweetened } \\
\text { beverage }\end{array}$ & Soda & $\begin{array}{l}\text { caffeinated } \\
\text { energe drink }\end{array}$ & $\begin{array}{c}\text { sweetened } \\
\text { beverage }\end{array}$ \\
\hline never & referent & referent & referent & referent & referent & referent \\
\hline 1-2 times/week & $\begin{array}{c}1.03(0.97- \\
1.09)\end{array}$ & $\begin{array}{c}1.10(1.04- \\
1.16)^{* *}\end{array}$ & $1.06(0.98-1.14)$ & $\begin{array}{c}0.95(0.90- \\
1.00)\end{array}$ & $\begin{array}{c}1.00(0.95- \\
1.06)\end{array}$ & $\begin{array}{c}1.09(1.01- \\
1.17)^{*}\end{array}$ \\
\hline 3-4 times/week & $\begin{array}{c}1.05(0.98- \\
1.13)\end{array}$ & $\begin{array}{c}1.07(0.98- \\
1.18)\end{array}$ & $\begin{array}{c}1.12(1.04- \\
1.21)^{* *}\end{array}$ & $\begin{array}{c}0.88(0.82- \\
0.94)^{* *}\end{array}$ & $\begin{array}{c}1.12(1.02- \\
1.23) *\end{array}$ & $\begin{array}{c}1.15(1.07- \\
1.24)^{* *}\end{array}$ \\
\hline 5-6 times/week & $\begin{array}{c}1.05(0.95- \\
1.15)\end{array}$ & $\begin{array}{c}1.20(1.01- \\
1.42)^{*}\end{array}$ & $1.09(0.99-1.20)$ & $\begin{array}{c}0.80(0.73- \\
0.89)^{* *}\end{array}$ & $\begin{array}{c}1.36(1.15- \\
1.60)^{* *}\end{array}$ & $\begin{array}{c}1.15(1.05- \\
1.26)^{* *}\end{array}$ \\
\hline \multirow[t]{2}{*}{$\begin{array}{l}1 \text { or more } \\
\text { times/day }\end{array}$} & $\begin{array}{c}0.99(0.89- \\
1.11)\end{array}$ & $\begin{array}{c}1.18(1.01- \\
1.38)^{*}\end{array}$ & $1.09(0.98-1.20)$ & $\begin{array}{c}0.74(0.66- \\
0.82)^{* *}\end{array}$ & $\begin{array}{c}1.13(0.96- \\
1.32)\end{array}$ & $\begin{array}{c}1.28(1.16- \\
1.41)^{* *}\end{array}$ \\
\hline & Fastfood & $\begin{array}{l}\text { Instant } \\
\text { noodle }\end{array}$ & Snack & Fastfood & $\begin{array}{l}\text { Instant } \\
\text { noodle }\end{array}$ & Snack \\
\hline Never & referent & referent & referent & referent & referent & referent \\
\hline 1-2 times/week & $\begin{array}{c}1.06(1.00- \\
1.12)^{*}\end{array}$ & $\begin{array}{c}1.10(1.05- \\
1.17)^{* *}\end{array}$ & $\begin{array}{c}1.14(1.06- \\
1.21)^{* *}\end{array}$ & $\begin{array}{c}1.18(1.11- \\
1.24)^{* *}\end{array}$ & $\begin{array}{c}1.06(1.00- \\
1.11)^{*}\end{array}$ & $\begin{array}{c}1.15(1.08- \\
1.22)^{* *}\end{array}$ \\
\hline 3-4 times/week & $\begin{array}{c}1.21(1.12- \\
1.30)^{* *}\end{array}$ & $\begin{array}{c}1.27(1.19- \\
1.36)^{* *}\end{array}$ & $\begin{array}{c}1.33(1.24- \\
1.43)^{* *}\end{array}$ & $\begin{array}{c}1.44(1.34- \\
1.55)^{* *}\end{array}$ & $\begin{array}{c}1.03(0.97- \\
1.10)\end{array}$ & $\begin{array}{c}1.47(1.38- \\
1.57)^{* *}\end{array}$ \\
\hline 5-6 times/week & $\begin{array}{c}1.15(1.01- \\
1.32)^{*}\end{array}$ & $\begin{array}{c}1.40(1.25- \\
1.56)^{* *}\end{array}$ & $\begin{array}{c}1.65(1.50- \\
1.81)^{* *}\end{array}$ & $\begin{array}{c}1.72(1.51- \\
1.96)^{* *}\end{array}$ & $\begin{array}{c}0.92(0.82- \\
1.02)\end{array}$ & $\begin{array}{c}1.77(1.62- \\
1.94)^{* *}\end{array}$ \\
\hline \multirow[t]{2}{*}{$\begin{array}{l}1 \text { or more } \\
\text { times/day }\end{array}$} & $\begin{array}{c}1.22(1.01- \\
1.48)^{*}\end{array}$ & $\begin{array}{c}1.45(1.24- \\
1.69)^{* *}\end{array}$ & $\begin{array}{c}1.63(1.47- \\
1.81)^{* *}\end{array}$ & $\begin{array}{c}1.66(1.37- \\
2.02)^{* *}\end{array}$ & $\begin{array}{c}0.88(0.75- \\
1.04)\end{array}$ & $\begin{array}{c}1.76(1.59- \\
1.94)^{* *}\end{array}$ \\
\hline & Fruit & Vegetable & Milk & Fruit & Vegetable & Milk \\
\hline $\begin{array}{l}1 \text { or more } \\
\text { times/day }\end{array}$ & referent & referent & referent & referent & referent & referent \\
\hline 5-6 times/week & $\begin{array}{c}0.93(0.87- \\
1.00)\end{array}$ & $\begin{array}{l}1.04(0.98- \\
1.11)\end{array}$ & $1.04(0.97-1.11)$ & $\begin{array}{c}1.06(0.99- \\
1.14)\end{array}$ & $\begin{array}{c}1.00(0.94- \\
1.07)\end{array}$ & $\begin{array}{c}1.10(1.03- \\
1.18)^{* *}\end{array}$ \\
\hline 3-4 times/week & $\begin{array}{c}0.86(0.81- \\
0.92)^{* *}\end{array}$ & $\begin{array}{c}1.06(1.00- \\
1.12)^{*}\end{array}$ & $1.06(0.99-1.12)$ & $\begin{array}{c}1.03(0.97- \\
1.09)\end{array}$ & $\begin{array}{c}1.13(1.08- \\
1.19)^{* *}\end{array}$ & $\begin{array}{c}1.29(1.21- \\
1.36)^{* *}\end{array}$ \\
\hline 1-2 times/week & $\begin{array}{c}0.83(0.78- \\
0.88)^{* *}\end{array}$ & $\begin{array}{c}1.19(1.12- \\
1.27)^{* *}\end{array}$ & $1.04(0.98-1.11)$ & $\begin{array}{c}1.09(1.03- \\
1.16)^{* *}\end{array}$ & $\begin{array}{c}1.29(1.21- \\
1.36)^{* *}\end{array}$ & $\begin{array}{c}1.30(1.23- \\
1.38)^{* *}\end{array}$ \\
\hline never & $\begin{array}{c}0.86(0.80- \\
0.93)^{* *}\end{array}$ & $\begin{array}{c}1.30(1.17- \\
1.44)^{* *}\end{array}$ & $1.03(0.96-1.11)$ & $\begin{array}{c}1.10(1.02- \\
1.19)^{*}\end{array}$ & $\begin{array}{c}1.52(1.38- \\
1.67)^{* *}\end{array}$ & $\begin{array}{c}1.32(1.23- \\
1.41)^{* *}\end{array}$ \\
\hline
\end{tabular}

The data is presented as odds ratio (95\% confidence interval)

$* \mathrm{p}<0.05$;** $\mathrm{p}<0.01$

\section{Figures}




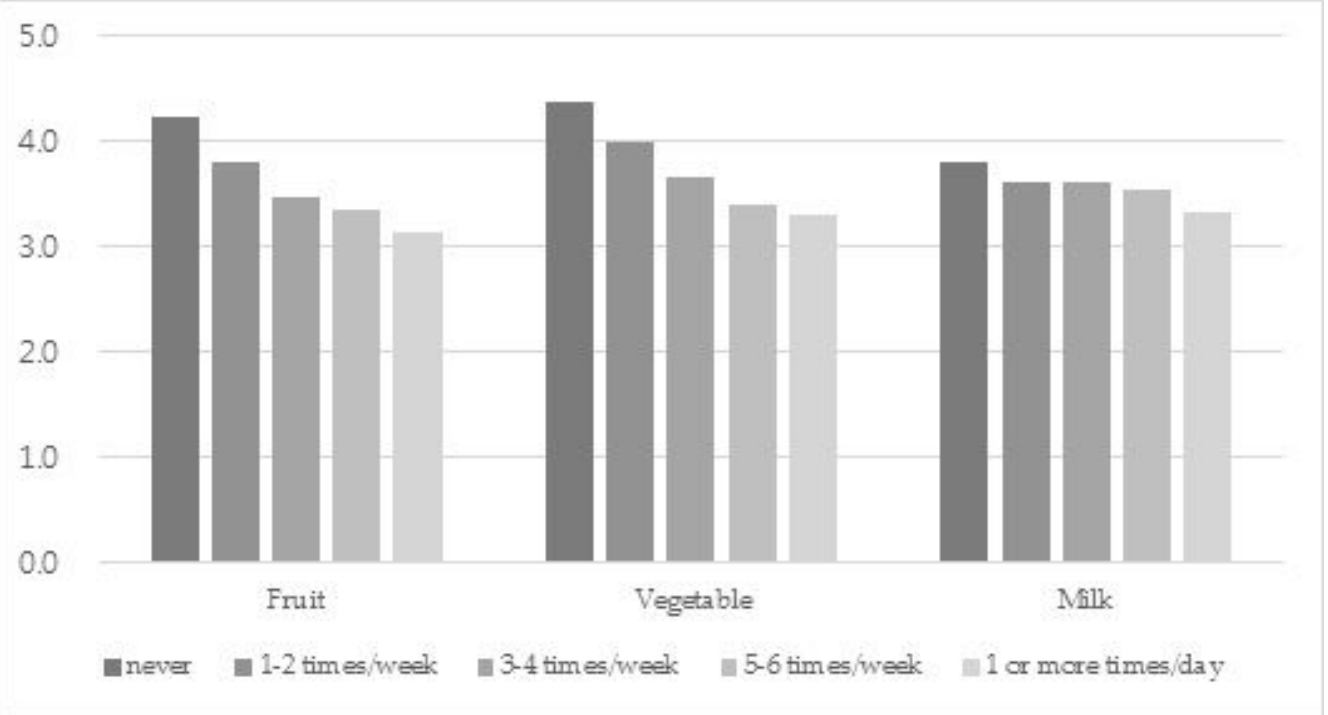

Figure 1

Smartphone usage time among the groups of food intake frequency (hours per day).

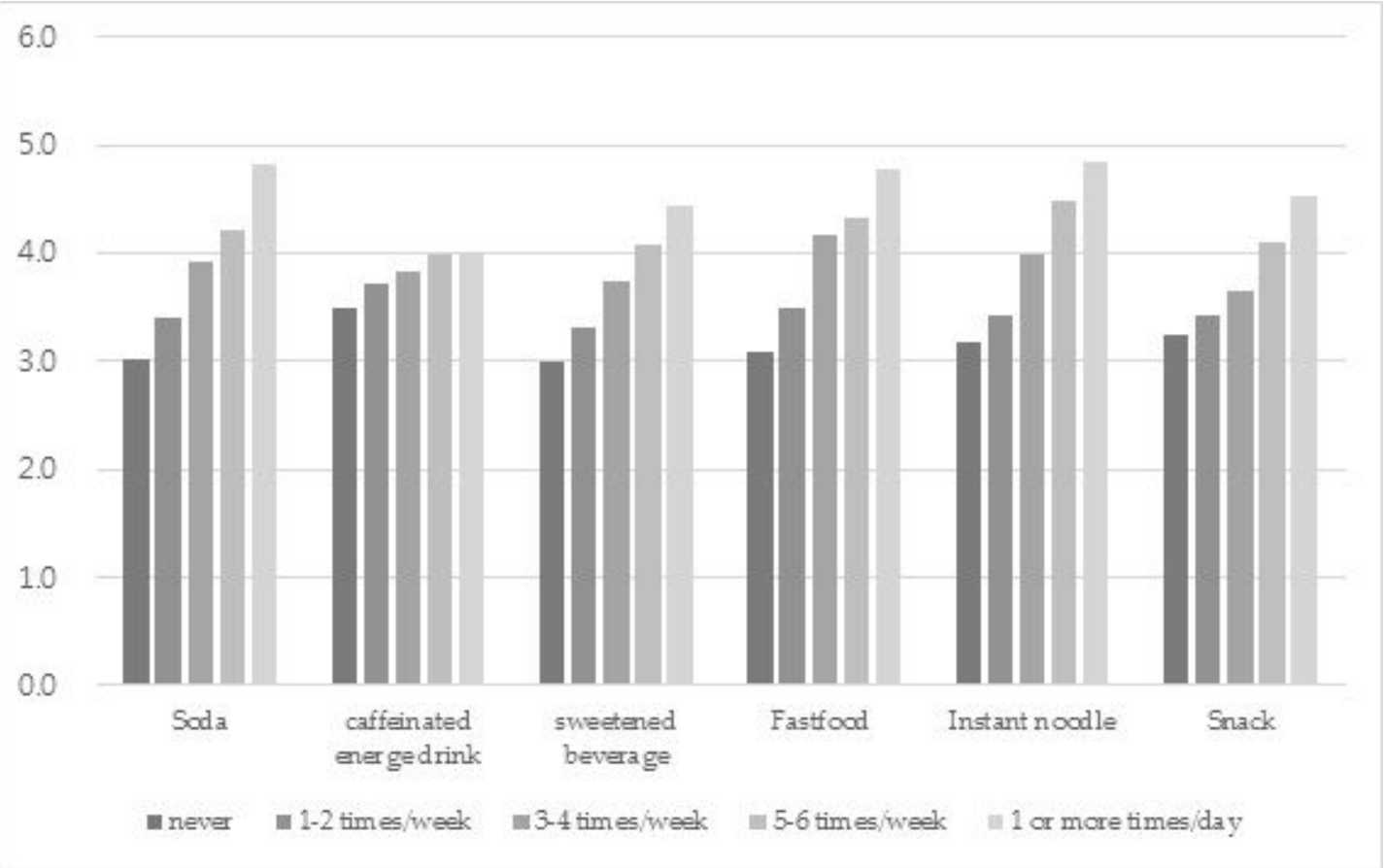

Figure 2

Smartphone usage time among the groups of food intake frequency (hours per day). 